\title{
Over the Weberian Wall: Chinese Family Businesses in Singapore
}

\author{
SieW TONG Fock ANd BARry WiLKINSON
}

\begin{abstract}
Overseas Chinese businesses have been characterized as possessing unique cultural attributes or being embedded in specific institutional environments that constrict their growth and lead to them taking on limited economic roles. Familism, particularism, nepotism and the lack of state support (among other cultural and institutional features) it is argued, stand in the way of the emergence of large, successful and enduring firms, and problems of inter-generation transition frequently lead to their demise. This paper argues that such a fatalistic prognosis is misplaced, and uses case studies of successful Chinese family businesses in Singapore to demonstrate how business leaders, as agents, can incorporate, defy, or re-combine elements from the socio-cultural environment in ways that enable continuity and growth. Additionally, this paper highlights the role of a proactive state at play in promoting a specific Chinese mode of doing business based on notions of so-called Confucian capitalism, which despite its culturalist associations, is based on capitalist practices.
\end{abstract}

Keywords: Chinese family business, inter-generation transition, chinese culture, entrepreneurial agency.

\section{Executive summary}

Previous studies have expressed pessimism regarding the possibility of the emergence of large, successful and enduring Chinese family businesses because of unique Chinese cultural attributes and unfavourable institutional environments that determine business structures and behaviour. The grounds for such pessimism are challenged in this paper. This paper goes against the mainstream perception of Chinese family firms as being held hostage to notions of (Chinese) culture and (Confucian) systems of belief, which together constitute what is referred to as 'the Weberian Wall'. Contrary to this view, the authors argue that culture and systems of belief can be employed in a proactive way, thus providing the Chinese entrepreneurs with a cultural specific identity in a capitalist dominated economy. The culturalist explanation of Chinese 
business practices, that is, at least in a Singapore context is rejected in this paper. Instead, it is argued that rather than their behaviours being determined by socio-cultural factors, Chinese family business practices, like other businesses, can draw selectively on the rules and resources found in the environment in which they are 'embedded' in order to exploit opportunities for growth and continuity. Additionally, this paper highlights that there is another factor that is at play, namely a proactive state. The Singaporean state has been very proactive in promoting a specific Chinese mode of doing business based on notions of so-called Confucian capitalism, which despite its culturalist associations, is soundly based in global capitalist practices.

Five case studies of successful Chinese family businesses in Singapore are used to explore the ways in which some Chinese family businesses have overcome the constraints on long-term stability, growth, internationalization and inter-generation transition that many scholars have identified. State-business relationships, nepotism and familism, and inter-generation transitions are generally considered to be key sociocultural features that delimit Chinese family business behaviour. The findings suggest that rather than wholly constraining or determining Chinese family business behaviour, Chinese family businesses can draw on these and other features of the socio-cultural environment to which they are exposed in order to develop their businesses beyond the limited roles they are assumed to accept.

The data reported provides useful insights for practitioners as well as academics. Agency has too often been ignored by academics studying the relationship between socio-cultural environments and the behaviour of Chinese family businesses. Instead, the assumption has too often been that socio-cultural attributes determine business behaviour and business structures that lead to a limited and specific role in the world economy. This is because ethnic Chinese states do not provide the support for businesses that might be culturally acceptable in other countries such as Japan; Chinese traditional inheritance patterns mean that inter-generation problems are so acute that Chinese businesses cannot survive and prosper in the long term - they are more likely to disintegrate or die; and the cultural emphasis on nepotism, familism and particularistic social relations limit the emergence of professional management (Tan \& Fock 2001). But in this paper business leaders and managers are recognized as active and reflexive participants in the business building process, where actors are engaged with a socio-cultural environment rather than being determined by that environment. Business 
leaders, as agents, can incorporate, defy, or recombine alternative rules and resources from the socio-cultural environment in ways that enable continuity and growth.

The five highlighted case studies of Chinese family businesses that have achieved success over a long period of time, that have internationalized, that have become more professional in orientation, and that have successfully completed inter-generation transitions illustrate how they managed to overcome the 'obstacles' to success, by actively drawing on rules and resources from their socio-cultural environments. Their success factors can provide insights for other Chinese family businesses, and should make both scholars and practitioners wary of the negative fatalistic predictions that dominate much of the literature in this area.

The authors of this paper have chosen to focus exclusively on Singaporean Chinese entrepreneurs while recognizing that other scholars of ethnic Chinese entrepreneurship in a Southeast Asian context have time and again stressed that Singapore is unique in this context. In the nine other ASEAN countries the state is not that proactive when it comes to Chinese entrepreneurship, as the Chinese in this region are generally perceived as having double standards towards national projects. In some Southeast Asian countries, it can be argued that they are even regarded as being a kind of 'fifth column' minority that cannot be trusted, especially now that Mainland China turns out to be one of the major economic challenges to the region. In the specific case of Singapore, the focus of this paper, since the Chinese in Singapore is not a minority but a majority, the state is naturally inclined to support the Chinese business community. This goes for both the major Chinese companies/conglomerates and the many Chinese small and medium enterprises so as to be able to get the best out of the Chinese business networks in the region as well as those reaching all the way into the mainland Chinese market.

\section{Introduction}

Weber (1930) attributed the emergence and development of capitalism in the West to the Protestant ethic, arguing that the Calvinist sought material success as an earthly confirmation of his position as a soul favoured by divine selection for salvation in the next life. While he postulated that the religious ideas of Protestantism provided an underpinning for the blossoming of capitalism, he also argued that capitalism later became an ideology in its own right - 'the spirit of capitalism' (Stark 
1992). According to Weber, this 'spirit' - a certain condition of the 'soul' - set the conditions for the industrial revolution. It was not underlying economic forces that created cultural products, including religion, but rather culture produced certain forms of economic behaviour (Fukuyama 1995).

Weber (1951) also argued that in addition to Protestantism, unique attributes of the West, particularly political expression and openness to modern thinking, contributed to the emergence of capitalism. This contrasted with the East ('the Orient') that was shackled by its culture, belief systems (in particular Confucianism) and social institutions. He argued that these formed a seemingly insurmountable wall for the emergence of capitalism in Chinese society.

The remarkable economic success of the overseas Chinese in the post-war period, most notably in Singapore, Hong Kong and Taiwan, but more generally in East and South East Asia, contributed to a rethink of Weber's ideas. 'Culturist' and 'institutionalist' scholars have rejected Weber's pessimism for the emergence of successful Chinese capitalism in the Orient, but insist on the importance of understanding the socio-cultural environment in shaping a unique form of capitalism, with different organizing principles that fit with those socio-cultural traditions. Chinese socio-cultural traditions are held to give rise to small, paternalistic family owned businesses that have difficulties in growing to a large size and becoming international, and that face acute problems in inter-generation transition. The 'wall' they identify is not so much a barrier to capitalism per se, but a barrier to the emergence of enduring, professionally managed, large international firms.

The five case studies of Chinese family businesses discussed demonstrate how it is possible for overseas Chinese firms to overcome the obstacles to growth, professionalization and to achieve successful intergeneration transitions, and provide a critique to those arguments that suggest that socio-cultural constraints are so powerful, entrenched and pervasive as to seal the fate of ethnic Chinese firms to remain, at best, niche players in global markets.

\section{Weber's cultural change thesis and its application in Chinese societies}

For Weber, a detailed understanding of culture requires an understanding of the role of beliefs in social life. Beliefs play a role via the dynamics of charisma and the creation of routines, the differentiation 
between spheres of life, and the inner logic of world-views (Schroeder 1992:9). Charisma is a driving, creative force that surges through the established rules governing an existing order. Over a period of time, there is a transformation from a new revolutionary message into routine teaching, followed by a gradual accommodation of the belief system to the interests of the followers. Making charisma a routine entails a regularization of activities, either by the formation of new norms or establishment of legal rules (Giddens 1992).

With reference to 'the differentiation between the spheres of life', for Weber, the most notable are the political, economic, religious and intellectual spheres. Each sphere of life makes certain demands on the individual's conduct, and they can either overlap, indicating a reinforcement of ideas between these spheres, or be differentiated, where they provide potential for the impact of new ideas. Hence, an overlap of spheres indicates social stability, whereas conflict between the spheres will increase the potential for change.

The third area in which beliefs play a role in social life relates to 'the inner logic of world views' and their relation to social forces. Weber believed that any change in world views arises from the conflict between the explanations offered by the belief system, and that of the empirical reality. This accounts for shifts in beliefs and cultural change. Weber believes that in everyday life an individual is confronted by a multitude of norms and beliefs. However, the individual will adhere simultaneously to different norms, and adopt a belief system with the potential for change in his social behaviour (Schroeder 1992).

For Weber (1951), despite the presence of two other Chinese religions - Buddhism and Taoism - Confucianism is still the primary influence on the social behaviour of the Chinese. Weber argued that Confucianism has a strong affinity to magic, which is seen to have a stabilizing or traditionalist effect on social life, creating a stagnant system of norms and conduct. The Chinese literati were a group of followers whose status and cohesion was based on a certain way of life. Their prestige rested on writing, a skill the mass believers associated with magic, and in their knowledge of Confucian literature. The believers would attempt to increase their social standing through extensive study of Confucian literature. Educational qualifications determined the positions people could hold in the ancient Chinese bureaucracy, and were solely dependent on the results achieved in the Chinese state examinations. According to Weber, Chinese religion and the other social spheres of life remained undifferentiated: instead, they reinforced each other 
(Schroeder 1992). The interplay between religion and social life can be found on three levels: the religious authority of the literati; the ancestor cult of the Chinese village; and patrimonial rule at the state level. The ancestor cult was the predominant form of religion on a societal level. It endowed kinship within the kin group (Sippe, or sib as used by Weber) with an aura of inviolability. Since familial piety is considered the highest of virtues under Confucianism, Chinese social relations, especially economic ones, would be dwarfed in priority by family ties in any decision making process. Traditional Chinese businesses have often been conducted on the basis of guanxi, and there were often blood relations between the owners of co-operating businesses. According to Weber, the Chinese literati attempted to orientate their behaviour in a way in which their actions would not subject interacting parties to undue shame. As Schroeder (1992:50) puts it, '... The watchful self-control of the Confucian was to maintain the dignity of external gesture and manner to keep face'.

Weber also argued that Chinese Confucianism served to perpetuate traditional values and existing institutions, and bound the Confucianist in the first place to maintaining the harmony of the divine and to an ideal of self-perfection which precluded the mere means-end calculation of utilitarian advantage. In short, Weber noted that China's traditional socio-political structure and the Chinese exaltation of the 'cultured man' as the highest Confucian ideal, did not involve or imply any demand from God - in contrast to Calvinist teaching in the West - for the people to work hard for profit (Weber 1951). Instead, Confucius integrated the old traditions of history, literature, culture and political governance and put them together with human experiences into a conceptual framework, which is now called Confucianism. The heart of Confucianism lies in the concept of Ren, which has been translated in English as love, benevolence, human-heartedness, perfect virtue, or humanity (Lu 1983). From this concept comes values such as loyalty, filial piety, righteousness, propriety, shame, trust and compassion, all of which most Chinese are exhorted to apply in their daily lives. As a consequence, there are three cardinal guidelines for behaviour: rulers guide subjects, fathers guide sons and husbands guide wives. (Some teachings follow five cardinal guidelines, which include guidelines governing elder-junior and friendfriend relationships). There are also five constant virtues: benevolence, righteousness, propriety, wisdom and fidelity (Kwok 1989).

Weber's analysis of Chinese society led him to argue for three major structural obstacles to capitalism: there were no self-governing and rule- 
making assemblies in China, hence the lack of independent power for bourgeois interests; the Chinese kinship system of organisation around a single clan meant that economic functions were limited by the division between insiders and outsiders; and there was a lack of an independent, rational legal system (Collins 1986). As a result, a barrier referred to as the Weberian Wall in this paper, stood between Confucianist China and modern capitalism.

Parsons (1937) summarised Weber's principle observations on the culture and economy of 'the East' and 'the West' as follows. Firstly, by contrast with other civilisations, rational bureaucratic organisation and closely related forms are major elements in the social structure of the modern West. Secondly, there is a congruence of the ethics of ascetic Protestantism with the bureaucratic rational bourgeois element of modern Western Capitalism and its 'geist'. Thirdly, there is a lack of congruence between the spirit of capitalism and the ethical implications of the major Asiatic religions. In so far as they have had an influence on secular social life it 'could not' have been in a rational bourgeois capitalist direction.

Building on Weber's work, Parsons (1951) further developed a scheme of pattern variables consisting of dichotomous concepts: affectivity versus affective neutrality; self-orientation versus collective-orientation; universalism versus particularism; achievement versus ascription; and specificity versus diffuseness. The modern type of 'industrial' occupational structure, Parsons observed, is characterized by a system of universal, specific, affectively neutral, self-oriented and achievement-oriented roles (Parsons 1951: 177). In contrast, the traditional Chinese social structure possessed a combination of opposite characteristics, which 'blocked the development of anything like capitalism' (Parsons 1951:179).

Parsons noted that the Puritan ethic represents an intensification of the general Christian tendency, with an extremely powerful animosity towards nepotism and favouritism. The Confucian ethic stands in sharp contrast. Its ethical sanction was given to an individual's personal relations with particular persons - and with any strong ethical emphasis only to these. The whole Chinese social structure accepted and sanctioned by Confucian ethics was predominantly a 'particularistic' structure of relationships.

Both Weber and Parsons observed that Chinese ethical precepts were personal and particular, and as such, the Confucian code just could not have the impersonal and universal quality of the Protestant ethic. Both are of the view that the Chinese precepts of Confucianism put a premium on emotional human bonds in all the undertakings of individuals. Hence 
while profit making and efficiency may be goals for the Chinese, they are not considered capable of achieving these goals at the expense of human relations or human feelings. As such, successful capitalism is limited or held back due to the existence of a 'Weberian wall' between Confucian values and behaviour and successful capitalism.

\section{Culturist and institutionalist schools of thought}

Whereas in the past, Weberian scholars suggested a restraining effect of Confucianism and traditional behaviour patterns in East Asian economies, today's culturist and institutionalist scholars draw selectively on Weberian and Parsonian sociology to explain both economic success and business formations in post-war Japan and the Asian newly industrialised countries (Singapore included). Culturists (Hampden-Turner and Trompenaars 1994; Hofstede and Bond 1988; Wong 1988; Kahn 1979; King 1985; Kuah 1990) emphasize Confucianist culture to explain success. They identify causal links between pre-modern worldly beliefs, cultural values, and modern organizational forms. Institutionalists (Hamilton 1996; Hamilton and Biggart 1988; Hamilton and Kao 1987; DiMaggio and Powell 1983; Whitley 1992) have explained organizational forms in relation to an 'institutional environment', and have asserted that economic success is in turn dependent on a fit between institutional environment and business behaviour.

Wilkinson (1996) points out that while both schools of sociologists draw on the work of Max Weber, they differ significantly in their interpretations of Weber's writings. Culturists suggest a causal relationship between pre-modern religious beliefs and modern organizational forms. Researchers such as Shepard et al. (1989) argue that rather than holding back the emergence of capitalism, Confucianism has provided the thrust for capitalist development. They accept Weber's (1930) thesis of a cultural basis for economic activity, but reject Protestantism as the sole religious foundation for capitalism. Instead, they believe that there are alternative development models that defy the conventional 'Western model' based on impersonal rationality, efficiency, and individualism (Khan 1979; Shepard et al. 1989; Tai 1989). Hofstede and Bond (1988) identified a 'cluster of values' among East Asians referred to collectively as "Confucianism Dynamism" (perseverance, thrift, a sense of shame, and hierarchical ordering of relationship by status). These values, associated with a 'Confucian work ethic', were found to be absent among Westerners involved in their study. 
The culturist approach has come under criticism from social scientists such as Meek (1988), who asserts that the culture of organizational life cannot be analysed in terms of a universal unitary concept. Institutionalists also criticise the culturists for displaying a lack of appreciation of other factors such as legal and political structures, and traditional relationships between individuals and groups in pre-modern societies.

Institutionalists base their analysis on Weber's idea of a link between social institutions and patterns of organization but (in a reversal of Weberian logic similar to that deployed by the culturists) disagree with Weber's view that traditional social institutions undermine Chinese capitalism (Schroeder 1992). Instead, they assert that business organizations are 'embedded' in an 'institutional environment' (Granovetter 1985), arguing that institutions such as the family and the state, which make up the organization's environment, play an influential role in their structure and behaviour. Because of the importance of 'embeddedness' in institutional environments (Granovetter 1992; Scott 1995; Ingham 1996), resources made available in the conduct of organizational activities depend not only on economic efficiency but also on social legitimacy (DiMaggio and Powell 1983; Meyer and Rowen 1976). Hence, powerful norm-enforcing institutions such as the state and the professions take their place alongside economic forces in explaining patterns of human organization (Oliver 1997).

Institutionalists emphasize the importance of traditional Chinese institutions in explaining enterprise organization and behaviour in which Confucianism is only one element (Hamilton and Biggart 1988; Whitley 1991). They argue that traditional kinship group cohesion and a patrimonial (as opposed to bureaucratic) state, instead of undermining capitalism as postulated by Weber, have been instrumental in the development of the East Asian versions of capitalism. The institutionalist perspective argues that the social and political institutions prevailing in a society significantly shape the attitudes and behaviours of individual entrepreneurs, and influence the development of entrepreneurship itself. In Chinese societies, state patrimonial structures, familism, equal inheritance among the sons, and particularistic social relations based on guanxi, are associated with a 'hit and run' or 'guerrilla' capitalism. Such a form of capitalism may create short term profits, but limits the size to which businesses can grow and creates problems of inter-generation transition (Sit and Wong 1989; Wong 1988; Yu 2001). Such accounts, which see enterprises as socio-cultural 'artefacts' (Fukuyama 1995; Redding 1990) have become highly popular, and have informed recent 
accounts of overseas Chinese firms' problems in the business press (see for instance Gilley 2000).

A major criticism of both culturist and institutionalist theories relates to the denial of the role of human agency in the organization and behaviour of businesses. According to Giddens (1992), within any social system, an individual is an agent who, in a rigid and routine way, monitors the course of his or her actions in day-to-day life. Giddens' arguments about human agency are consistent with the observation that while Confucianism and traditional social institutions may restrain the behaviour and daily interactions of Chinese family business leaders within Chinese communities or in a societal context, Chinese family business leaders are not nevertheless devoid of choice in their actions and interactions with others.

\section{The role of human agency}

In analysing the relationship between the individual and society, Dawe (1978) described a contrast between social action and social system perspectives. He pointed out that when social action is seen entirely as the derivative of a social system, actors are pictured as having their behaviour determined. In contrast, social action perspectives emphasize the capabilities of individuals or groups to respond in different ways to systemic pressures, with the possibility that they might contribute to a change in 'the system'. Drawing on the work of Giddens, Whittington (1992) notes that within any society there are divergent, sometimes contradictory, organising principles which can be exploited by managers to gain agency, and which offer the opportunity of strategic choice. If this is admitted, then 'the relationship of particular actors to society becomes less one of passive embeddedness, and more a matter of active engagement' (Whittington 1992:704). Similarly, Seo and Creed (2002) argue that social actors can be 'active and artful exploiters of social contradiction' and draw on alternative logics of action to pursue organizational change.

Jack and Anderson (2002) pursue this theme in their study of embeddedness and entrepreneurial agency among small businesses in rural Scotland. They demonstrate how agency is not a process whereby economic actors are conditioned by the cultural and institutional environment. Rather, social embedding was consciously pursued in ways that enabled entrepreneurs to recognize and realise opportunities by acquiring local knowledge, opportunities and resources. These opportunities 
were found to exist within the structure, but only became manifested by the action of entrepreneurial agency. Structure and agency - social system and social structure - exist in a dynamic relationship. Societal influences shape entrepreneurial agency, and agency redefines and develops structure.

Smith and Meiksins (1996) point out that institutional theory is liable to treat innovation and change as merely the result of external shocks. In the context of this study, if we followed institutional logic, we would have to assume that successful inter-generation transitions and growth of some Chinese family businesses in Singapore was due entirely to external factors which affect the whole 'population' of Chinese family businesses uniformly. That being the case, it would never be possible to understand why some Chinese family businesses succeeded while others failed, in spite of the presence of seemingly constraining cultural and institutional factors that create pressures for conformity. In this study, the aim is to understand how organizations (specifically Chinese family businesses in Singapore) can incorporate, or defy, or recombine, those elements of the cultural and institutional environment in ways that lead to change. To be able to do this, we need to adopt a perspective that attends to human actors as sources of change and differentiation rather than mere passive recipients of 'cultural and institutional logics'.

\section{Research methods}

In attempting to understand, through a study of second-generation Chinese family business leaders, the key factors that enabled their businesses to successfully complete inter-generation transition and overcome the 'Weberian wall', primary empirical data was obtained from focused in-depth interviews, and complimentary secondary data was taken from a range of published sources. These methods enabled us to collect detailed information regarding the problems and challenges faced by second-generation leaders, and how they were overcome.

The case studies were chosen according to the following criteria: they must be Chinese family businesses that have survived at least two generations of family members; they must have an established track record of profitability up to mid-1997 (i.e. before the East Asian economic crisis) and thereafter continue to be in business; they are healthy in terms of financial strength as indicated by their registered annual sales, gross and net profit financial figures, and they have demonstrated the potential for growth and are not likely to be wound up in the near future; they 
have cumulative pre-tax profits of at least $\mathrm{U} \$ 5$ million for the last three years, and a capitalisation of at least US\$10 million that would qualify them to be listed on the Singapore Exchange of Singapore. Five Chinese family businesses were studied that met these criteria, and whose family business leaders were available and willing to consent to focused in-depth interviews.

The five Chinese family business cases selected for this research met the above criteria, and they also represented a reasonable cross-section of large and successful Chinese family businesses across different lines of business in Singapore. The selected five cases are: The Hour Glass Company Limited; Eu Yan Sang International Limited; Qian Hu Corporation Limited; The Hong Leong group of companies in Singapore; and Popular Holdings Limited. Each of these five well-known Chinese family businesses is managed by second-generation family leaders, and in the case of Eu Yan Sang International Limited, by a fourth generation family member. They have also succeeded in globalizing their operations and the scope of their activities, and are thriving today. (Descriptions of other Chinese family businesses in Singapore that meet these sorts of criteria can be found in Tan and Fock 2001.)

The interview method - using semi-structured questionnaires - provided the flexibility and control to gain an insight into the perspectives of the Chinese family business leaders in these five firms. This is of course essential to any study of human agency, enabling an understanding of the motivations, dilemmas, interests, etc. of the subjects. It is of course recognized that in spite of the many advantages of in-depth interviews as a research tool, there are well known inherent limitations. For instance the interviewer may suffer from what may be described as from a 'double dose of subjectivity', interviewees may indulge in understatement or overstatement, and there are the usual problems of generalisation. Nonetheless, the case studies do provide valuable insights into the ways in which overseas Chinese business leaders have interpreted both the internal and external environments in which they operate, and how they could respond to those environments in ways that enabled them to escape their supposed cultural and institutional straight jackets.

The primary purpose of the research was analytical rather than descriptive, but before proceeding with the analysis, a brief description of the five Chinese family businesses studied is provided. The descriptions were generated from our interviews, and where possible were corroborated by published sources. 


\section{Research findings and analysis}

\section{The case study firms: A brief overview and history}

Eu Yan Sang Group (Eu Yan Sang) manufactures and markets (through its retail outlets and other wholesalers) traditional Chinese medicine products under the brand name 'Eu Yan Sang'. A household name in Asia for the last 121 years, Eu Yan Sang is a leader in the traditional Chinese medicine industry. The Group currently offers more than 150 products and over 1,000 types of Chinese herbs and other medicinal products through its 52 retail outlets in Singapore, Hong Kong and Malaysia. It also exports to over 2,000 wholesalers and retail outlets all over the world.

The holding company of the group was listed on the Main Board of the Singapore Exchange in July 2000. With involvement of the fourth generation of the Eu family, Eu Yan Sang has gone beyond the 'threegeneration trap' advocated by many scholars to be common in Chinese family businesses.

Eu Yan Sang was founded on 23 July 1879 in Perak, Malaysia by the late Eu Kwong Pai (better known as Eu Kong). He left his hometown in Foshan, Southern China to seek his fortune in Malaya, eventually achieving success in the tin mining business. His first Chinese medical shop was set up for the benefit of tin mine workers. After he passed away in 1890, his son Eu Tong Sen diversified his tin mining business into rubber and expanded the peripheral TCM business with branches in Malaya, Hong Kong and Singapore. After his death, the businesses were split between his many children, each under a loose sole proprietorship structure until Eu Yan Sang's operations were converted into a limited company in 1955. When it came to the third generation, there was a notable lack of entrepreneurial drive, family members only being interested in collecting dividends from their shareholdings. The Company briefly came under the control of the Lum Chang Group in 1990 until the fourth generation family members, under the entrepreneurial leadership of Richard Y. M. $\mathrm{Eu}$, engineered a successful reverse takeover of the traditional Chinese medicine business. Subsequently, Eu Yan Sang grew by leaps and bounds and was able to establish a regional presence, transforming itself into a successful Chinese family-based international corporation.

The Hour Glass Limited (Hour Glass), in the span of 21 years, grew from a local company in Singapore with just a single watch retail outlet to become a publicly listed company with 13 retail outlets in Singapore, 
Malaysia, Thailand, Hong Kong and Australia, specialising in the retailing and distributorship of luxury Swiss watches. It is run by Jannie Tay and her husband Henry Tay together with active involvement of third generation family members, particularly in this instance, Michael Tay, the son of Henry and Jannie who is now an Executive Director of Hour Glass.

Hour Glass was founded in 1979 by Jannie Tay and her husband, Henry Tay, when they formed THG together with Metro Holdings Ltd (Metro) after Jannie had helped her husband and his first generation family members in their family's watch business. Jannie Tay revolutionised the watch business by creating a new image as a luxury watch retailer and distributor. With the experience of modern management styles gleaned from the partnership with Metro, the company expanded its operations in the late 1980s to broaden its customer base and to cater to a wide range of market segments. Hour Glass also established outlets in Australia, Malaysia, Hong Kong, Indonesia and Brunei. The third generation of the Tays were roped in towards the end of 1999, when Jannie Tay began a planned succession process for her two children.

The Hong Leong Group (Hong Leong) is one of the biggest Chinese family-owned conglomerates in Asia. From a modest beginning after being established in 1941 by the founding patriarch, Kwek Hong Png, a migrant from the Fujian province in China, the group has grown over the last 62 years to become one of Asia's most successful and largest diversified international business empires. While the group has expanded its global presence, it remains essentially a Chinese family-owned and controlled group of the Kweks.

Kwek Hong Png arrived in Singapore in 1928 at the age of 16 to work in his brother-in-law's hardware business. Thirteen years later, he set up Hong Leong Company to deal in ropes, paints, and rubber estates supplies, inviting his three brothers to join him. In the 1950s and 1960s, Hong Leong ventured into manufacturing (in line with the Singapore government's industrialization goals) through joint ventures with giant Japanese firms. In the mid-1960s, the Kweks' family business turned to the acquisition of property. During the period of Indonesia's confrontation with Singapore when property prices in Singapore were low, and throughout the 1960s and into the 1970s, Hong Leong amassed one of the largest land banks in Singapore at very low cost. The next major strategic move came during the second half of the 1960s. Hong Leong became a leader in yet another field - the provision of loans to small industries - when it started Hong Leong Finance in 1966. Hong Leong 
Finance grew rapidly to become the largest finance company in Singapore. During all this time, critical decisions covering many aspects of the Singapore business, particularly property, were made by Kwek Hong Png, who adopted a management style that varied from authoritarian paternalism to benevolent paternalism.

In 1990, four years prior to the death of Kwek Hong Png, his eldest son, Kwek Leng Beng, took over the leadership mantle of the group as the family's second-generation entrepreneurial leader when he became the chairman of the Hong Leong group. Under him, the group became a large Chinese family conglomerate with extensive global operations in hotels, property, financial services and manufacturing. His contribution to the successful international growth of the Hong Leong Group can be attributed to three factors. Firstly, having joined the family business in 1963 after his graduation in law from the University of London, he had the benefit of learning the business from his entrepreneurial father for more than 30 years. Secondly, Hong Leong had a flat management structure that facilitated the quick decision making style typical of entrepreneurial leaders of large and successful Chinese family businesses. Thirdly, Kwek Leng Beng had developed a more professional corporate profile for the group to facilitate its aggressive globalization plans. This included the building up of a core team of professionals and not confining management to family members.

Qian $\mathrm{Hu}$ Corporation Limited (Qian $\mathrm{Hu}$ ) is engaged in the import and export, farming and distribution of ornamental fish, as well as the distribution of aquarium and pet accessories. One of Singapore's two top exporters of ornamental fish, Qian Hu exports directly to more than 45 countries. The company also has subsidiaries in Malaysia, Thailand and the PRC. Incorporated on 12 December 1998 as Qian Hu Fish Farm Pte Ltd, Qian Hu was converted to a public company on 13 October 2000 and assumed its present name Qian Hu Corporation Limited. The company made history when it became the first fish farm to be listed on the Singapore Exchange on 8 November 2000.

Qian Hu had humble beginnings in a pig farm in Sembawang, when the late Yap Tik Huay (father of Chairman and Managing Director Kenny Yap) and his brother were forced to turn to fish breeding after the Singapore Government closed down all pig farms in 1985. In 1993, Kenny Yap became the managing director and his appointment heralded a new beginning for the family farm. The youngest of five brothers and the only graduate, he, together with four brothers and two cousins, spearheaded the overhaul of work processes that saw Qian Hu's sales quadruple. 
Buoyed by a string of successes, Qian Hu decided to seek listing on the Singapore Exchange, and hence embarked on several restructuring exercises to streamline the various businesses of the Yap family. Qian Hu Fish Farm was later listed on 8 November 2000 as Qian Hu Corporation Limited. The reasons for the listing, as cited by Kenny Yap, were to end the family business mentality and to obtain funds from the initial public offering so as to aid expansion. However, much control still remained in the hands of the Yap family.

Popular Holdings Limited started out 77 years ago as a Chinese book distributor. It has since expanded its business into the three core businesses of retailing, publishing, and distribution of Chinese and English books and office stationery. As a publicly listed company on the Main Board of the Singapore Stock Exchange, its operations are now established in Singapore, Malaysia, Hong Kong, Macau, the People's Republic of China, Taiwan and Canada. It is essentially a family-owned business of the Chou family, led by a second-generation family member, Mr. Chou Cheng Ngok (C. N. Chou).

Popular Holdings Limited (Popular) was established in 1924 by the late Chou Sing Chu, father of the present Chairman, who migrated to Singapore from China to start a small Chinese bookshop. This was followed by expanded operations in Kuala Lumpur, Penang, Indonesia, Kunming and Hong Kong. After graduating with an MA in Political Science from Wayne State University in the U.S., C.N. Chou returned to join the family business in 1964. In line with Singapore's emphasis on the teaching of English in schools in the 1970s, he repositioned Popular in 1975 to become 'The Bilingual Bookshop'. He also expanded Popular's operations with the opening of more retail outlets in Singapore and in Taiwan and its publishing business was extended into Canada. He is also credited with Popular's ventures into public housing estates and well known for identifying choice retail locations.

\section{Analysis of the findings}

The analysis draws further on interview materials in order to assess how each of the five case study firms has grown to a substantial size, become more professional, progressed down the road of internationalization, and most importantly, successfully completed inter-generation transitions. How was this possible in the face of the overwhelming constraints identified by culturist and institutionalist scholars? Here we assess the supportive role of the Singapore state, then examine the ways in which the Chinese family business leaders actively dealt with the constraints 
of nepotism, familism and equal inheritance identified by culturist and institutionalist scholars in order to overcome the 'Weberian wall'.

\section{Role of the state}

Unlike the Imperial Chinese state as discussed by Weber, from its inception in the 1960s following the end of the British colonial period, and under the leadership of the charismatic Lee Kuan Yew, the ethnic Chinese dominated Singapore state, did not 'leave the people at rest' regarding their economic lives as institutional theory might predict, but took a lead role in developing an export oriented economy based on the attraction of multi-national companies. Until the mid-1980s the state lavished generous incentives to export-oriented multi national companies, and took various measures to create the well educated, disciplined and cooperative labour force that multinational companies preferred (Deyo 1991; Pang 1982). However, the 1985 economic recession led to a re-evaluation of government policy that shifted emphasis towards local entrepreneurs as the engine of growth. Since then the government has introduced a range of initiatives aimed at helping local enterprises improve their technological capabilities and develop into international markets, and opened up new opportunities for local businesses to benefit from the privatization of government-owned corporations. Each of the five case study firms had in recent years been aided in their development and growth by the Singapore government. For instance, Qian Hu is one of 97 companies that received financial grants in 1997 under the Singapore government's S\$500 million Innovation and Development Grant Scheme. In addition, Qian $\mathrm{Hu}$ has received tangible and intangible encouragement from the Economic Development Board (EDB), Productivity and Standards Board (PSB), and the Agri-Food \& Veterinary Authority of Singapore (the erstwhile Primary Production Board).

In the case of Popular, the support it received was not in terms of financial assistance, but more in terms of consultancy services provided by various government bodies. An example of this was PSB's proposal for Popular to franchise its operations.

Hour Glass benefited indirectly from the activities of the Singapore Tourist Promotion Board, which deliberately increased the number of foreign tourists to Singapore. This was important to Hour Glass's core business in Singapore, particularly since the expansion stage of its development was dependent on a growing base of well-off foreign tourists as their customers. In addition, as stated by Jannie, the recognition of the performance of Chinese family businesses such as Hour Glass 
in the early 1990s through the National Awards of Excellence, was an important factor in encouraging the development and growth of local enterprises, including her own.

Hong Leong was also a beneficiary of the environment created and incentives offered by the government. As Kwek Leng Peck put it during the interview, 'the government in Singapore had made it possible through good governing practices and planning for the Hong Leong group to grow from modest beginnings to an internationally acclaimed global business empire'. Hong Leong worked closely with governmental investment bodies such as the Government Investment Corporation (GIC) in joint-venture business investments overseas. (GIC is Singapore's ultimate investment and holding company for Singapore external investments in excess of US\$100 billion). Examples of these joint ventures are the joint purchase in 1996 of the Marriott hotel in Hong Kong for S\$390 million (US\$153 million) (Straits Times 26 November 1996), and the successful clinching of a $\$ \$ 41.3$ billion (US $\$ 16.2$ billion property development along the proposed city-airport railway line (Business Times 8 November 1996).

To summarise, the Singapore state is a conscious agent capable of making choices about economic policies in the light of alternative development models. While Confucianist values are embraced and espoused by the state, it hardly behaves in the aloof and distant manner that would be predicted by institutional theory - indeed it prides itself on its pragmatic interventions. Further, our research findings suggest the state's recognition of a central role for Chinese family businesses in the development of the economy from the mid-1980s gave a boost to Chinese family businesses by materially supporting their development and contributing to the enhancement of their legitimacy

\section{Nepotism and familism}

Interviewees in the five Chinese family businesses shared many Chinese cultural values with first generation leaders, and they applied these cultural values in the management of the Chinese family businesses. However, they all had professional backgrounds and prior exposure to Western management concepts and techniques, such that they were at ease with introducing modern management practices. Hence Confucian values may now be tempered with the 'Western dynamism' Weber found in Protestant Europe.

All the interviewees insisted that Chinese cultural values such as honesty, frugality, family consultation, hard work, education, persever- 
ance, prudence, and filial piety were important, and more importantly, these values were passed down to them by their parents. Arguably they contributed to the success of their businesses. For instance the late founder of Hong Leong, Kwek Hong Png, had little formal education (similar to the other first generation founding patriarchs in our other case studies) but he placed high importance on the value of education and professional training. Both his sons (the elder Kwek Leng Beng graduated as a lawyer from the University of London and the younger Kwek Leng Joo graduated in business from a university in Japan) had overseas university educations. In the case of Qian $\mathrm{Hu}$, we were told that the late founder Yap Tik Huay passed critical values down to his children - Executive Chairman Kenny Yap and his four brothers - and that these have shaped the management culture of today's family business. These are: integrity, diligence, loyalty, trust, filial piety, the importance of lifelong learning, and team work and family unity. Qian Hu's rise from a small fish farm to a global ornamental fish exporter known for the quality of its products and innovative use of technology was explained to us in these terms.

Even though the present Chairman of Popular Holdings, C. N. Chou, spent a large part of his life overseas, he said during an interview that his cultural value standards are firmly rooted in Chinese culture. $\mathrm{He}$ ensures his staff members constantly practise lifelong learning by undergoing a systematic developmental training curriculum that provides opportunities to develop their potential to the fullest. Like his father, he places great importance on the value of education for his staff, and he emphasizes the importance of education as a Confucian tradition.

Sending children to the some of the best universities in the world, however, brings with it professional knowledge and new outlooks on life. Confucian traditions do not appear to die, but they do become tempered by alternative perspectives on how to conduct business. Researchers such as Fukuyama (1995) and Kao (1993) have highlighted the lack of trust exhibited by Chinese family business leaders in nonfamily professionals in the Chinese family business. In Weber's view, the cohesion of the kin group prevents the formation of the impersonal contractual relations that are required by the modern capitalist enterprise (Schroeder 1992). Jannie Tay of Hour Glass had such an experience with her husband's family watch shop, Lee Chay \& Co. Watch Shop. Lee Chay was conservatively managed by family members from an earlier generation to that of Jannie and Henry who had a great distrust for non-family members and all authority in decision-making flowed 
from the first generation Chinese family business leader. Stifled by the family's 'staid management style', Jannie Tay left to set up Orchard Watch Company and later founded Hour Glass in 1979. Jannie Tay was an agent in the development of international activities and professional standards.

Tsang (2002) points out that in becoming an international enterprise, Chinese family businesses tend to rely heavily on the owner-manager in strategic decision-making, and family members will fill key expatriate positions, giving rise to a concentration of (tacit) strategic knowledge. This management style has the advantage of fast decision-making and avoidance of leakage of knowledge to competitors, but relies on a 'fragile organisational memory', and on family members who may not necessarily be culturally adaptable. Further, local managers may be discouraged at the lack of promotion opportunities. The Chinese family businesses in our study have recognized such limitations in sending their children to be educated in foreign countries, through promoting more non-family members into senior management positions, and through taking steps towards the professionalization of management.

All five cases suggest that Chinese family businesses can grow to successful operations across national borders, and have the potential capability to transcend the Weberian wall to become professionally managed multinational enterprises, while at the same time retaining some of their traditional cultural values. For instance, the presence of the Eu family members ensures the continuity of the family's heritage, while the professionalization of management brings new business ideas and the ability to become international enterprises. During the postWorld War II period, the third generation left Eu Yan Sang operations to trusted professional managers. They were able to contribute to the growth and development of Eu Yan Sang in Hong Kong, Singapore and Malaysia because the third generation family members did not practise paternalism, nepotism or personalism. Instead professionals were trusted and given substantial autonomy to manage the Chinese family business. Since the corporatization of Eu Yan Sang under the fourth generation family members, more professionals were brought in to serve at senior management levels. Hong Leong's flat management structure facilitates quick and effective decision-making, thus providing distinctive advantages in the successful development and growth of global operations.

Qian Hu's management culture similarly represents a blend of modern techniques and traditional Chinese values. Yet Kenny Yap is aware 
that, like other Chinese family businesses, Qian Hu often faces difficulty in attracting the best professionals into the family business because of remaining negative perceptions of constraints on career prospects in family businesses. Hence Qian Hu has taken steps to gradually separate management and ownership of the company so that it can be more professionally run. The management team has introduced a performance-based reward system and other new management policies aimed at reducing the company's reliance on family members in the day-to day running of the business, while empowering key staff members with greater job flexibility and responsibility.

In Hong Leong, the late Kwek Hong Png was always at ease in interacting with professionals such as senior lawyers and bankers and, as pointed out by his nephew Kwek Leng Peck (one of the second generation Chinese family business leaders of Hong Leong), he was skilled at integrating the old intuitive managerial style with the new modern professional approach by recruiting outside professional managers to work alongside his western educated sons and nephews.

In each of the case study firms, while traditional values and particular relationships were clearly in evidence, there was a clear tendency to move away from nepotism and family favouritism towards the establishment of professional standards of behaviour.

\section{Inter-generation transitions}

Inter-generation transitions in family businesses are well recognized as a key problem (Dyck et al. 2002; Morris et al. 1997). Morris et al. (1997) identify three sets of determinants of successful transition: the preparation of heirs, the quality of trust relationships among family members, and planning for taxation and wealth transfer, with family relationships being of key importance. For Chinese family businesses, the same problems may arise, though the importance of family trust relationships may be even more salient because of the traditional practice of equal inheritance.

Defying the fatalistic prognosis of the Weberian wall is of course no easy feat. Eu Yan Sang almost hit the 'wall' during the third generation from the early 1930s to the late 1980s. The lack of a clear succession plan by second-generation Eu Tong Sen contributed to a 'fragmentation dilemma' whereby equal inheritance essentially prevented any branch of the family from controlling the Chinese family business. This problem was only resolved when a fourth generation family member (Richard Y.M. Eu) entered the Chinese family business to consolidate Eu Yan Sang's operations under common ownership and management. 
Inter-generation transition remains something of a problem at Eu Yan Sang today. The children of the fourth generation family members are still very young, and it is inevitable that there will be one layer of senior management dominated by non-family members before the fifth generation can enter senior positions. However, Richard Y.M. Eu made it clear in interview that the children will not be forced to enter the Chinese family business if they have no affinity for the business. He believes that the future success of Chinese family businesses in growing from generation to generation rests with the capability and competence of their successors rather than the fact that they are family members per se. This view was echoed by Kenny Yap of Qian $\mathrm{Hu}$, who is emphatic that future generations should be given a chance to decide for themselves whether they are interested to be in the family business.

Echoing the views of other Chinese family business leaders, C.N. Chou said that it was crucial to find a successor to continue the business into the next generation. He has no problem in having one of his competent professional managers succeed him in the event that no family member is available to take over the mantle of leadership. His preference is clearly to have a family member to continue the family business from one generation to the next, but he is ready if necessary to pass the reigns to non-family members.

Each of the stated Chinese family businesses provides evidence that succession in inter-generation transition must be viewed as a process, and there are two critical points that are particularly important in determining success. The first is when the succeeding Chinese family business leader is placed in a leadership position, and the second is when he or she takes over as the successor. In the five Chinese family businesses we studied, succeeding family members had to earn their legitimacy as leaders by 'proving themselves' early in their 'working careers'. As would be predicted by Morris et al. (1997) congenial family relationships, especially between the incumbent family leader and the succeeding leader, are extremely important in effecting a smooth transition, with the incumbent leader mentoring the successor. The cases also reveal that it is useful for the incumbent Chinese family business leader to know the strengths and limitations of potential successors and to appoint them to appropriate positions where they can 'learn the business' prior to their ascension. This is attested by the thirty years of tutorship and mentorship that the founder of Hong Leong, Kwek Hong Png, had given to his son, Kwek Leng Beng. 
The development of the five Chinese family businesses is very much dependent on succession. At Eu Yan Sang the absence of an entrepreneurial leader in the third generation almost led to the loss of the family business in 1990. However, the Eu's firm was re-positioned to grow to become a leading international producer and retailer of traditional Chinese medicine and other healthcare products and services in Asia and beyond. This was largely down to entrepreneurial skills of the Richard Y.M. Eu.

In the case of Hour Glass, Jannie Tay is the driving force. Assuming responsibility at a young age, she was sent abroad to Australia to study and had to take care of her younger siblings after her father passed away. After leaving Lee Chay and forming Hour Glass, she assumed leadership and overcame many problems to succeed in her business ventures. This was at the same time as she was bringing up her children, including a physically disabled daughter, and coping with the death of another daughter.

In Hong Leong, Kwek Leng Beng was well prepared for his role as the entrepreneurial leader by his father. Before assuming the top leadership position, he had initiated the takeover of a loss-making listed company, City Developments, and turned it around into a leading listed property group in Singapore. This was in fact the first corporate takeover mounted by the group. In 1979, he launched a takeover of listed Singapore Finance Limited, boosting the size of Hong Leong's finance operations. These takeovers proved to be invaluable lessons for Kwek Leng Beng later when he targeted hotels abroad.

Kenny Yap of Qian Hu is another entrepreneurial leader who has brought success to his Chinese family business by 'moving the entire company philosophy forward'. However, he is quick to point out that the success of his Chinese family business is a team effort. In an interview given to the Asian Entrepreneur magazine, he commented that the key determining factor to explain the success of Qian Hu relates to the acceptance of his leadership by the rest of his family members and in their 'willingness and eagerness to try new concepts and methods in the business' (Asian Entrepreneur March/ April, 1999: 119). Qian Hu is at the forefront of the industry by constantly improving its business techniques. As he stated in an interview: 'an entrepreneur must be ready to change the culture of his industry by introducing new ways of doing things'. As the youngest second-generation member of the Yap family, Kenny Yap is intent on making full use of his privileged overseas education to do his best for the family's business. 
As the family leader in the business, Popular's C.N. Chou sees that the he has to lead in cultivating a sense of both entrepreneurship and professional standards in his company. His goal, like his father's goal, has always been to create a 'corporate entrepreneurial culture' in Popular, and for his staff to act in an entrepreneurial manner. While he has encouraged the professionalization of his company's management team, he feels that his non-family professional managers can be further developed to be entrepreneurs too. To encourage his senior staff to understand that the essence of entrepreneurship is making proprietary decisions (Kao 1995) and to facilitate this behaviour, he has implemented a staff share-option scheme.

\section{Conclusion}

The 'Weberian wall' poses difficulties, but is not insurmountable. The case studies demonstrate how Chinese family business leaders have actively and consciously combined Chinese values and traditions with alternative rules and resources in order to overcome some of the problems associated with family ownership and control.

Chinese family business leaders have been aided in their ability to do so particularly via a pro-active state and the overseas education of succeeding generations, who have brought professional standards and diluted the nepotism, particularism and familism for which they are renowned. At the same time, they have continued to assert the primacy of Chinese values such as frugality, integrity and life-long learning. This may appear contradictory, but then contradiction and ambiguity is inherent in all social change (Dawe 1978). The Chinese family business leaders interviewed, successfully drew from a range of rules and resources to which they had been exposed - from overseas experience, from the state, from multi-national companies based in Singapore, and of course from their families - in order to incorporate, defy, or recombine elements from the socio-cultural environment that enabled continuity and growth. They did so consciously, displaying an awareness of the 'barriers' to the introduction of, for instance, professionalization and innovation, and seeking to establish these attributes in ways that did not wholly destroy family business traditions. Of course, more Chinese family businesses fail than succeed, but that is true of family businesses the world over.

From this research, it is not possible to deduce conclusively whether Chinese family businesses in Singapore are converging towards a 
'Western' style of business, or developing a modified form of business unique to Chinese Singaporeans. However, the research findings certainly do not contradict those of Holt (1997) who argues that Chinese entrepreneurs in the Peoples' Republic of China, although still influenced by Confucianism, have been willing when necessary to pragmatically adopt certain so-called 'Western' values such as professionalism, and dilute the salience of nepotism and particularism, in pursuit of business success and continuity. Chinese family businesses, like other family businesses, engage in conscious and reflexive behaviour, drawing on alternative values and alternative organizing principles. They are active agents in change and development, not the mere passive recipients of cultural and institutional logics.

Siew Tong Fock (corresponding author) is Associate Dean (Development) and Associate Professor of Banking and Finance at Nanyang Technological University's Nanyang Business School in Singapore (astfock@ntu.edu.sg); Barry Wilkinson is Professor of International Management at the University of Exeter's School of Business and Economics (barry.wilkinson@exeter.ac.uk).

\section{REFERENCES}

Asia Pacific Economic Co-operation Conference 1994. Survey on SMEs.

Asian Entrepreneur. March/April Singapore 1999:119.

Chan, K.B. and C.S.N. Chiang 1994. Stepping Out: The Making of Chinese Entrepreneurs. Singapore: Prentice Hall.

Chew, K.H. and M. Goh 1996. 'Entrepreneurship as an engine of growth in the Singapore context'. In A.M Low et al. (eds). Entrepreneurs, Entrepreneurship and Enterprising Culture. Singapore: Addison Wesley 1996: 223-234.

Clark, M. 1990. Anthony Giddens: Consensus and Controversy. New York: Falmer Press.

Collins, R. 1986. Max Weber: A Skeleton Key. US: Sage.

De Souza, D. 1996. 'Confucius meets Max Weber'. Forbes, New York, 4 November 1996.

Daft, R.L. 1995. 'Why I recommended that your manuscript be rejected and what you can do about it'. In L.L Cummings et al. (eds). Publishing in the Organizational Sciences $\left(2^{\text {nd }} e d n\right)$. Thousand Oaks: Sage.

Dawe, A. 1978. 'Theories of social action'. In T.Bottomore et al. (eds). A History of Sociological Analysis. New York: Basic Books 1978: 362-417.

Deyo, F. 1991. Beneath the Miracle: Labour Subordination in the New Asian Industrialis. Berkeley: University of California Press.

DiMaggio, P.J. and W.W. Powell 1983. 'The iron cage revisited: institutional isomorphism and collective rationality in organisational fields'. American Sociological Review 48: 147-160.

Dyck, B., M. Mauws, F.A. Starke and G.A. Mishke 2002. 'Passing the baton: the importance of sequence, timing and technique in executive succession'. Journal of Business Venturing 17:143-162. 
Fukuyama, F. 1995. Trust: The Social Virtues and the Creation of Prosperity. New York: The Free Press.

Giddens, A. 1992. Capitalism and Modern Social Theory. Cambridge: Cambridge University Press.

Gilley, B. 2000. 'Pulling Away'. Far Eastern Economic Review 10 February: 42-46.

Granovetter, M. 1985. 'Economic action and social structure: the problem of embeddedness'. American Journal of Sociology 91 (3): 481-510.

Granovetter, M. 1992. 'Economic institutions as social construction: a framework for analysis'. Acta Sociologica 35: 3-11.

Hamilton, G. 1996. 'The theoretical significance of Asian business networks'. In Hamilton G. (ed). Asian Business Networks. Berlin: de Gruyter 1996: 283-298.

Hamilton, G. and N. Biggart 1988. 'Markets, culture and authority: a comparative analysis of management and organisation in the Far East'. American Journal of Sociology 94 (Supplement): 52-94.

Hamilton G. and C.S. Kao 1987. 'Max Weber and the analysis of the East Asian Industrialisation'. International Sociology 2/3: 289-300.

Hampden-Turner, C. and F. Trompenaars 1994. The Seven Cultures of Capitalism. New York: Doubleday.

Hofstede, G. and M. Bond 1988. 'The Confucian connection: from cultural roots to economic growth'. Organisational Dynamics 14 (4): 5-21.

Holt, D.H. 1997. 'A comparative study of values among Chinese and US entrepreneurs: pragmatic convergence between contrasting cultures'. Journal of Business Venturing 12: 483-505.

Ingham, G. 1996. 'The new economic sociology'. Work, Employment and Society 10 (3): 549-564.

Jack, S.L. and A.R. Anderson 2002. 'The effects of embeddedness on the entrepreneurial process'. Journal of Business Venturing 17: 467-487.

Kahn, H. 1979. World Economic Development: 1979 and Beyond. London: Croom Helm.

Kao, J. 1993. 'The worldwide web of Chinese business'. Harvard Business Review MarchApril: 24-36.

Kao, W.Y. 1995. Entrepreneurship: A Wealth-Creation and Value-Adding Process. Singapore: Prentice Hall.

Khoo, C. and C.J. Chua 2000. Singapore savy 50:50 entrepreneurs of tomorrow's Singapore. Singapore: PHP International.

King, A.Y.C. 1985. Confucian ethics and economic development: a re-examination of Max Weber's thesis. Proceedings of the Conference on Modernization and Chinese Culture. Hong Kong, Faculty of Social Science and Institute of Social Studies, Chinese University of Hong Kong.

Kuah, C. E. 1990. 'Confucian ideology and social engineering in Singapore'. Journal of Contemporary Asia 20 (3): 371-383.

Kwok, D.W.Y. 1989. The Chinese Tradition: An Essay. Occasional Paper No. 3. Honolulu: Center for Chinese Studies.

Lu, M. 1983. Confucianism: Its Relevance to Modern Society. Singapore: Federal Publications.

Meek, V. L. 1988. 'Organisational culture: origins and weaknesses'. Organisational Studies 9 (4): 453-473.

Meyer, J. and B. Rowan 1976. 'Institutionalized organisations: formalized structures as myth and ceremony'. American Journal of Sociology 83 (2): 340-363.

Morris, M.H., R.O. Williams, J.A. Allen and R.A. Avila 1997. 'Correlates of success in family business transitions'. Journal of Business Venturing 12: 385-401. 
Oliver, C. 1997. 'Sustainable competitive advantage: combining institutional and resource-based views'. Strategic Management Journal 18 (9): 607-713.

Pang, E.F. 1982. Education, Manpower and Development in Singapore. Singapore: Singapore University Press.

Parsons, T. 1937. The Structure of Social Action. New York: The Free Press.

Parsons, T. 1951 The Social System. New York: The Free Press.

Productivity Standards Board, 2000. SME21: Positioning SMEs for the $21^{\text {st }}$ Century. Singapore: Singapore Productivity and Standards Board.

Redding, G. 1990. The Spirit of Chinese Capitalism. Berlin: de Gruyter.

Schroeder, R. 1992. Max Weber and the Sociology of Culture. Sage, London.

Scott, W. 1995. Institutions and Organizations. Thousand Oaks: Sage

Seo, M. and W. Creed 2002. 'Institutional contradictions, praxis, and institutional change: a dialectical perspective'. Academy of Management Review 27 (2): 222-247.

Shepard, J.M, C.H. Chung and M.Dollinger 1989. 'Max Weber Revisited: Some Lessons from East Asian Capitalistic Development'. Asia-Pacific Journal of Management 6 (2): 307-322.

Singapore Census Report, 1990. The Singapore Government.

Sit, V. and S.L. Wong 1989. Small and Medium Industries in an Export-Oriented Economy: the Case of Hong Kong. Hong Kong: Centre of Asian Studies, University of Hong Kong.

Smith, C. and P. Meiksins 1996. 'System, society and dominance effects in cross-national organisational analysis'. Work, Employment and Society 9 (2): 241-267.

Stark, R. 1992. Sociology. California:Wadsworth Inc.

Tai, H.C. 1989. The Oriental alternative: A hypotheses on culture and economy. In H.C. Tai (ed). Confucianism and Economic Development. Washington:Washington University Press:6-37.

Tan, C.H. 1989. 'Confucianism and nation building in Singapore'. International Journal of Social Economics 3 (8): 5-16.

Tan, W.L. and S.T. Fock 2001. 'Coping with growth transitions: the case of Chinese family businesses in Singapore'. Family Business Review 14 (2):123-140.

Business Times, Singapore. 8 November 1996.

Straits Times, Singapore. 26 November 1996, 2 February 1997, 15 August 1999.

Tsang, E.W.K. 2002. 'Learning from overseas venturing experience: the case of Chinese family businesses'. Journal of Business Venturing 17: 21-40.

Weber, M. 1930. The Protestant Ethic and the Spirit of Capitalism. London:Allen \& Unwin.

Weber, M. 1951. The Religion of China: Confucianism and Taoism. Illinois: Free Press. Glencoe, Illinois.

Whitley, R. 1991. 'The social construction of business systems in East Asia'. Organization Studies 12 (16): 1-28.

Whitley, R. 1992. Business Systems in East Asia. London: Sage.

Whittington, R. 1992. 'Putting Giddens into action: social systems and managerial agency'. Journal of Management Studies 29 (6): 693-712.

Wilkinson, B. 1996. 'Culture, institutions and business in East Asia'. Organization Studies 17 (3): 421-447.

Wong, S. L. 1988. 'The applicability of Asian family values to other sociocultural settings'. In Berger, P. (eds). In Search of an East Asian Development Model. New Brunswick: Transaction Books. 1988:135-152.

Yu, F.L. 2001. 'The Chinese family business as a strategic system: an evolutionary perspective'. International Journal of Entrepreneurial Behaviour and Research 7 (1): 22-40. 